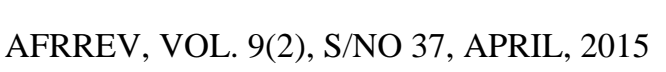 \\ African Research Review
}

An International Multidisciplinary Journal, Ethiopia

Vol. 9(2), Serial No. 37, April, 2015:78-90

ISSN 1994-9057 (Print) ISSN 2070-0083 (Online)

DOI: http://dx.doi.org/10.4314/afrrev.v9i2.6

\section{Role Reversal Protest in Nigeria: Soldiers Still the Boss? A Behaviouralist Inquiry into the Incessant Soldiers-Police Violent Conflicts in Lagos}

\author{
Eesuola, Olukayode Segun \\ Department of Political Science \\ University of Lagos \\ E-mail: foomoterribly@yahoo.com
}

\begin{abstract}
Today's world is used to all sorts of inter-group violent conflicts, but definitely not the type in the post military Nigeria where soldiers and policemen fatally combat each other; soldiers claiming superiority over policemen who, in turn, want to seize every opportunity to act that in a democracy, they, no longer the soldiers, are the boss. This is a "role reversal protest" triggered by, first, the bossy and "save our souls' Nigerian soldiers who had controlled political power until 1999; second, the inability of the post military government to make adequate provision for the management of soldiers, thereby exposing them to regular contacts with civilians. The third factor is the highhandedness of some Nigerian policemen in the process of enforcing the law. In an exploration of the situation, this paper asserts that such role reversal protest is inevitable in most post military rule societies, but is pronounced in Nigeria owing to the given reasons. The paper canvases appropriate policies and practices to manage the protest in order to prevent degeneration to institutional rivalry between the military and the police: a development that can crush Nigeria's avant grade democracy. Some policies are suggested based on common practices around the world. Also, the role of the civil society is emphasized.
\end{abstract}


Key words: Role Reversal Protest, Post military Soldiers, Inter Group Conflicts, Partisan Ruling/Dominant Class, Military Privileges

\section{Introduction}

Politics is about struggle for power in the state. This power, in the words of First (1970), primarily lies in the barrel of the gun. In fact, Machiavelli asserts that "A political unit without military power is not a state" (Cited in Adekanye 2008, p.15), and Adekanye (2008) corroborates it by stating that "states are defined by their monopoly of military functions, the legitimate command of force" (p. 15). It does appear therefore, that the power of a state is synonymous with the power of its military, and military power is a reflection of the power and influence a state commands locally and in international politics. But what happens where the military with its superior power of legitimate coercion has become very much used to control of politics but has to relinquish it by reason not of its weakness or willingness, returning under the control of civilian authorities where highhanded policemen are the boss? Role reversal protest often results, and, at present, it is causing a lot of ripples in Nigerian polity.

The Nigerian soldiers have bossy mercenary orientation, and they ruled the country in an interregnum for more than thirty five years after independence. During the interregnum, soldiers controlled everything everywhere: education, health, politics, university admission, government contracts and all sorts. The military suspended the constitution to enjoy absolute dictatorial powers and unlimited privileges. Nigeria was a colony of military generals administered by the rank and file in the military (Greene 1997, CDHR 1999). Eventually, however, after series of conspiratorial political power games described by Diamond et al (1997) as "transition without end", as well as agitations from individuals such as Fela Anikulapo Kuti, Beeko Ransome Kuti, and Gani Fawehinmi; then the Campaign for Democracy, CD; the Civil Liberty Organization, CLO and the National Association of Nigerian Students, NANS; soldiers officially vacated Nigeria's political arena in 1999, and the country re-established democratic structures of government. Since then, the country has been democratizing.

In a democracy, however, the police enforce the law, and, as no respecter of either person or institution, the law has to be enforced even on soldiers who have superior fire power and have dictatorially controlled politics until 1999. But soldiers are still everywhere in the country: in politics and trade; on streets, in commercial buses and general stores; and, from their actions and inactions, they largely consider unimaginable, probably abominable, a polity where they, as the 'boss' for many years, will accept to be controlled by highhanded, "bloody civilian" Nigerian policemen who enforce the law. 
This situation, which has generated series of violent conflicts between soldiers and policemen since 1999, breaching public peace and creating human casualties from both sides, is what this paper calls role reversal protest: where soldiers resist being controlled by policemen and the policemen, in turn, enforce the laws with such highhandedness that shows that in a democracy, they, no longer the soldiers, are in charge. The human and material cost of such clashes, as well as the implication they have on democratization and the overall political development of Nigeria cannot but provoke scholarly interrogation from the behavioural scientist, hence, the attempt of this paper to explore it and proffer solutions. What, in the character of Nigerian soldiers, has made it difficult for them to submit themselves to civilian authorities after military rule? Why are the soldiers still everywhere and in everything since 1999 when military rule ended? How do the Nigerian policemen themselves enforce the law, and what can be done to manage the soldiers- policemen violent conflicts in a bid to ensuring better overall civil military relations and survival of democracy in Nigeria? These are the questions that this paper tries to explore in four parts.

After this introduction comes a trajectory interrogation of the Nigerian soldiers from the colonial period till date, interrogating their character. The nature of civil policing in Nigeria is also examined, viz a viz the post military democratic governments and its inability to make certain provisions to manage the military and mediate as an unbiased umpire between soldiers and civil authorities. Conclusion and recommendations follow.

\section{Soldiers in Nigeria's Political History}

Every country positions its soldiers as the highest security stakeholders, those that are authorized to use all forms of force through all forms of sophisticated weapons. The task of soldiers is usually defined as defence of the state and its citizens, as well as prosecution of war against external aggression. So, whether in war or peace, soldiers use brutal force as peacekeeper in international conflicts, or as defender of the state against internal and external aggression.

The military is the institution that produces soldiers, but soldiers in the modern African states are peculiar. This is primarily because African military "originated from the forces of European occupation and control" (Claude E. Welch, jnr, In Ejiogu 2007), so, from north to south, west to east, soldiers are forceful and violent. The Nigeria's armed forces originated from military forces assembled by different British agents whose activities culminated in the colonization of parts of the Niger basin, which became Nigeria" (Ejoogu 2007:4), and, until independence in 1960, soldiers were used extensively in internal operations that basically employed excessive forces on Nigerian peoples who challenged the authorities of the colonial masters. Between 1929 and 1930, for instance, soldiers were deployed to suppress the 
anti-tax uprising by women in parts of Igboland and the neighbouring Ibibioland. Ejiogu (2007) reveals that

all British agents who operated in the Niger basin relied on disaffected individuals to raise military forces for their conquest of its inhabitants. For instance, during his tenure (1861-73) as the Lieutenant Governor of the Lagos Crown Colony, Lt. John Glover enforced compliance to Crown authority with the militia that he raised earlier on as an imperial adventurer/agent in Yorubaland from runaway Hausa slaves. In 1903, almost half a century later, the bulk of the force that Frederick Lugard deployed in his campaign against the Fulani rulers of Hausa land comprised of runaway Hausa slaves and other disaffected and marginalized individuals in Hausaland (pp. 4-5).

The history of Nigeria military dates to 1863 , when Lt Glover of the Royal Navy selected 18 indigenes from the Northern part of the country and organized them into a local force known as the 'Glover Hausas'. "The small force was used by Glover as Governor of Lagos to mount punitive expedition in the Lagos hinterland and to protect British trade routes around Lagos" (info.army@army.mil.ng). Since 1863 the army has passed through many stages, most of which are for mercenary and colonial protection purposes. In 1865 it became Glover Hausa, in 1867 Hausa Constabulary, and it later got renamed as Lagos constabulary two years after. The same army was incorporated into the West African Frontier Force, became the Lagos Battalion in 1901 and remained so till Lord Lugard later used it for expeditions during the annexation of Nigeria between 1901 and 1903 ((info.army@army.mil.ng).

As an organization made to protect the interest of the colonial masters and the elite, as well as enforce laws and regulations imposed on the people in the Nigerian colony, (Ejiogu 2007), the military played vital role in quelling anti colonial struggle and nationalism in Nigeria. It was used extensively during election into the First Republic before it finally intervened in politics in 1966. In fact, Ejiogu expressly asserts that "During colonialism, the Nigerian army remained the machine for internal repression of first and last resort in the hands of colonial administrators who deployed it handily to counter and neutralize internal threats to colonialism"(pp.3). Prima facie therefore, the history of the Nigeria soldiers is laden with violence, elitism and punitive expeditions.

Direct military control of political power began after independence. General Aguiyi Ironsi instituted the first military regime in Nigeria, in 1966, followed by that of General Yakubu Gowon who ruled from the latter part of 1966 to 1975. General Muritala Muhammed ruled from 1975-76, but was assassinated in a palace coup, making General Olusegun Obasanjo the inheritor of power from 1976 to 1979. There 
was a break in the interregnum, and civilian government returned between 1979 and 1984, led by Alhaji Shehu Shagari. Another coup came up December 31, 1983, and a military government was reestablished by General Muhammadu Buhari who was later toppled by General Ibrahim Babangida who ruled the country for eight years, stepping aside in 1993, and appointing Earnest Sonekan as interim head of state. The military took over again after six month, presenting General Sani Abacha as new Head of State. General Abacha's government was interrupted by his untimely death, and General Abdlsalami Abubakar emerged to continue military rule before handing over to civilian politicians and returnlng Nigeria to democracy in 1999 (Frynas, 1998).

As Adekanye (1997) observes, there were two kinds of soldiers in Nigeria during military rule: soldiers in political power and soldiers in barracks, but there was only a thin line between them as all soldiers were perceived by the public to be in power during military rule. The police as well as other civil authorities accorded soldiers a host of privileges ranging from special budgetary allocations, preference in national appointments, ownership of land and access to oil resources, admission to higher institution and job placement for wives and children of military officers. In all these the rank and file soldiers are involved, and the privileges equally extended to them. It is difficult for soldiers coming from the foregoing background to quickly adjust to any reversal of role brought by democracy. The policemen too who witnessed military rule and how it subordinated them to soldiers will likely protest all forms of further domination and control by soldiers.

This is the sense in the $\mathrm{J}$ Curve thesis of revolt. According to Jakobsen (2012), Davies propounded this theory in 1972, basing his argument on the analysis of the Dorr's rebellion, the Russian revolution, and the Egyptian revolution. The main thrust of the theory is that role reversal provokes revolts and protests, so, "revolutions are most likely to occur when periods of prolonged improvements concerning economic and social development are supplanted by a period of sharp reversal. Such sharp reversal of development and role creates an intolerable gap between what people want and what they get". In Nigeria, the role reversal between soldiers and policemen is based on power, but with serious implications on economic and social values of the two groups.

Furthermore, the role of the military is fast changing and becoming ever inclusive around the world today. Edmund (2006) identifies four ways in which this has happened globally, and, by extension, why the military cannot but still see itself as the boss. According to him,

The first is a decline in the significance of the defence of national territory as a core organizing principle for regular armed forces. The second is the increasing dominance of a model of military 
profession-alization that equates 'modern' armed forces with smaller, highly skilled, flexible force structures able to project power abroad, whether for war-fighting or peace-keeping operations. The third is the emergence of a number of 'new' security challenges, such as terrorism, drug smuggling and illegal migration that have refocused military roles on internal security issues. The fourth is the continuing salience of a wider domestic social and political role for armed forces.

In line with this, soldiers that are supposed to be in the barracks in Nigeria's a democratic disposition are constantly drafted to assist the police and other civil authorities in resolving advanced social conflicts and vices such as ethno religious riots and insurgencies, as well as high crimes such as armed robbery, kidnapping, terrorist activities and so on. Apart from this, soldiers are also involved in conduct of elections to forestall breakdown of law and order.

What is the character of the policemen in Nigeria, and how have they been policing the public? In August 2010, the Human Rights Watch presented a report based on interviews with more than 145 victims of, and witnesses to police corruption in Nigeria. The report database include market traders, commercial drivers, sex workers, criminal suspects, and victims of common crimes; rank-and-file and seniorlevel police officers; federal government officials; judges, prosecutors, and lawyers; religious and civil society leaders; journalists; diplomats; and members of an armed vigilante group. Based on this report, the Human Rights Watch concludes that corruption and highhandedness are extremely rampant within the police, and they come in forms of embezzlement, where funds that are meant for particular purposes are pilfered by top officers; system of returns, where officers demand money as returns from the bribe that policemen take on the roads they are posted to, as well as all forms of extortions, most of which are done at the expense of justice, public safety and general oversight.

Aside the issue of corruption, the Nigerian policemen are equally very lawless. They are the main culprits of breaking the very laws that they are paid to enforce. For instance, Nigerian policemen constantly drive against traffic, ply the BRT lanes in Lagos, and most of their vehicles are not in any way roadworthy as they drive without lamps, mirrors and other safety features - offences for which they arrest and prosecute others. With bossy soldiers parading streets and public places after they had been in charge of political power and enjoyed special privileges for a long time, policemen enforcement of the law with the highhandedness that often accompany it will most likely generate protest that will in turn catalyze fatal conflicts in the society. In what follows we discuss selected cases of such conflicts in Lagos, the economic capital of Nigeria. 


\section{The Ojuelegba War of 5th October 2005}

This refers to the soldiers - police violent clash that led to destruction of lives and property in Ojuelegba, a popular commercial centre of Lagos. It was estimated that seven people died and property worth one billion naira was destroyed. Nairaland gives a vivid report of what transpired:

The kata-kata began when some enterprising policemen, needing a patrol vehicle, decided to commandeer a commercial bus for that purpose. Unfortunately, a couple of soldiers who were among the passengers in the bus ... ordered all the passengers to stay put rather than disembark as ordered by the policemen. A "man pass man" struggle ensued, with the result that the unarmed soldiers were beaten into submission and hauled off to the police station... Word of the kidnapping got back to the nearby army barracks, and before you could holler "take cover", battle-ready troops in full Rambo regalia launched a coordinated assault on the police station, causing many a policeman to scale the perimeter wall under a hail of fire, and then burning the station, a car park full of vehicles and for good measure, the police barracks itself (Nairaland; my emphasis).

\section{The Badagry Massacre}

The Badagry Massacre of May 23rd, 2011 followed the foregoing Ojuelegba imbroglio. Reporting for the Vanguard Newspaper, Albert Akpor writes that the imbroglio occurred when

An army Staff Sergeant attached to 242 Reconnaissance Battalion, Ibereko Barracks in Badagry, was allegedly shot dead by policemen of the Lagos State Security outfit, the Rapid Response Squad (RRS) at a checkpoint in Badagry. The victim, who was on a motorcycle at the time of the incident, allegedly did not stop for police checks. In an attempt to enforce the law, the man was shot dead by a policeman (Vanguard Newspaper, 24th May 2011). Following the incident, a group of heavily armed soldiers from the 242 Recce Battalion, Iberepo, Badagry took over strategic locations in the ancient town maiming and killing any police man on sight in an apparent reprisal of the killing on Monday, of one of their colleagues,...in mufti who was escorting goods from the NigerialSeme border (and) was accosted by a police officer attached to RRS and Monday and demanded to search the vehicle (Vanguard, May 2011; my emphasis). 
Another report from the Vanguard Newspaper sheds more light on the matter, claiming that the soldier did not stop for police check, and threatened to disarm the policeman if he did not allow the vehicle free way; prompting the trigger happy policeman to fire at him at close range ( http://www.vanguardngr.com).

\section{Deductions from the Two Conflicts}

The first issue deducible from the two soldiers-police conflicts reported is that Nigerian soldiers are bossy and unready to succumb to control of civilian policing in the democratic Nigeria. Even when the policemen had no legal base for hijacking commercial bus for patrol and ordering all passengers therein to disembark, the soldiers, if had acceded that policemen should enforce the law in a democratic setting, should not have given a counter order ordering all the passengers to stay put rather than disembark as ordered by the policemen. The ideal thing was for them to have reported the excesses of the policemen to their superior officers in the nearest police station. The action of the soldiers was therefore a protest against the capacity and audacity of bloody civilians to give commands where they, the soldiers, were. Similarly, that the soldier allegedly did not stop for police checks but rather threatened to disarm the policeman that stopped him, in the case of Badagry, was apparently a soldier's assumption of superior training and status over policemen on the street.

The issue of bossiness and superiority claim of the Nigerian soldiers is further buttressed by the soldiers' handling of the two crises. Soldiers got the news of the molestation and killing of their colleagues and decided to, in the case of Ojuelegba, invade police station and burn it, and, in that of Badagry, take over strategic locations maiming and killing any police man on sight. These soldiers were protesting against the insult perceived to have been meted on them and the military institution by the bloody civilian policemen who wanted to control them. It is this bossiness and arrogance of the armed forces that Fela Kuti reported in his song, Government of Crooks (1988), when he wrote:

This is my country

Nobody suppose harass me

Police and soldier no go gree,

For my countryo

Zombies wan be oga

Zombies cannot be oga,

How zombies can be oga,

Zombie na zombie o.
This is my country

Nobody is supposed harass me

But policemen and soldiers won't let it

For my country o

Soldiers want to be the boss

Soldiers cannot be the boss

How can soldiers be the boss?

A soldier is a soldier

Copyright (C) IAARR, 2015: www.afrrevjo.net

Indexed African Journals Online: www.ajol.info 
Popular musicians are social commentators, historians and sometimes socializers (Ayu 1986, Street 2005, Okolo et al, 2010, Eesuola 2012), and in the above lyrics, Fela reveals the long time bossy struggle by Nigerian soldiers to control everything and everybody, reinforcing that what the soldiers did by launching a coordinated assault on the policemen and their stations in the two conflicts is a means of using force to protest against control of policemen, as well as reaffirming recognition among policemen and other citizens that even after military rule, soldiers are still superior.

Another deduction is that the post military government soldiers have not been well managed in the current democratic regime. Soldiers who occupied the commercial bus in the Ojuelegba were supposed to be in the barracks, and whatever reason that took them outside the barracks to mingle with civilians inside a commercial bus would simply be wrong, more so in that number. Nigerian soldier were involved in everything during military rule. They engaged in trading, education, contract award and all sorts. With the end of military rule and their return to the barracks, a gap will definitely exist in their lives. This explains the situation in the Badagry massacre where one of the soldiers in mufti, was escorting goods along the NigerialSeme border, a route that is globally notorious as smugglers'?

The incidents also confirm the highhandedness of policemen in Nigeria. The Nigerian law does not empower any policeman to hijack privately owned commercial bus for any form of operation, let alone 'enterprise' as described by the Vanguard; and the enterprise of the police in Nigeria is usually for extortion and harassment of people as Anikulapo Kuti (1989) sang in one album that When you wear police uniform, na to collect money for road; Na big wahala for man to waka for road at any time (ODOO, 1989; Police wey no get destination harass the man(woman) wey get destination (COP, 1989). It is the character of many Nigerian policemen to harass innocent citizens everywhere they are. To that extent, the policemen involved in the Ojuelegba imbroglio where the unarmed soldiers were beaten into submission and hauled off to the police station were in free display of power drunkenness, highhandedness and corruption. Same goes for the trigger happy policeman who fired the Badagry soldier; he was equally lawless and highhanded, as no law permitted him to gun down extra judicially, an unarmed person, soldier or otherwise.

Another flowing conclusion is the partisanship of the government and the political class. The Nigerian government as well as its dominant class is partisan, and lacks the capacity to mediate neutrally in most conflicts, including the one between soldiers and the police. The reason behind this is political. Nigeria state is yet to evolve hegemonic order, so, depending on the incident and the actors involved, the law is often applied selectively, and any faction of the ruling elite that is in control of political power often uses it to oppress and suppress the others. 
There was a good example in Rivers State where the federal government was alleged to have used the police and soldiers to suppress political rallies organized by the opposition APC, while the ruling PDP would organize same rallies under the full protection of the police (Daily Independent, 2004). Till today, no soldier has been brought to legal justice for their role in both the Ojuelegba war and the Badagry Massacre by any authority at all, and there is no order from the President Commander in Chief of Armed Forces to do so. No policemen has also been charged or disciplined for the highhandedness displayed to provoke the imbroglios. The two incidents under study occurred in Lagos, a state controlled by the opposition party, APC. The governor and chief security officer of Lagos is involved in treacherous political opposition to the PDP-controlled federal government whose leader, by the constitution, is the commander-in-chief of the Armed Forces.

\section{Summary}

In summary, therefore, the paper has so far established that based on their orientation, evolution and the fact that they had controlled political power until 1999, enjoying unlimited dictatorial powers and privileges, the Nigerian soldiers are bossy to the civilian citizens and are quite unlikely to take any form of order or control from policemen. In addition to the orientation, the Nigerian government has poorly managed the post military rule soldiers. When the Vanguard reported that "The Badagry incident is a gruesome dimension to unhealthy inter-force rivalries in the country... especially on the ubiquitous Lagos-Badagry smuggling route, and that the Badagry mayhem may not be unconnected with the struggle to control the lucrative smuggling route by the various forces, with each trying to outdo the other", what is indirectly meant is that the post military soldiers lack adequate provision and consequently engage in illegal activities such as smuggling in order to survive.

On the other hand are the highhanded Nigerian policemen, some of whom are also involved in smuggling but will want to act, playing the law enforcement role in the face of the public. Such policemen are not likely to be respected or tolerated by the ordinary public, let alone the Nigerian soldiers who have always been clamming superiority, so, the struggle that results from the control of road may not but constantly cause violence. In addition, Nigerian policemen, like the soldiers are equally bossy, lawless and highhanded, and such excesses from them provoke reactions from soldiers. That the post military Nigerian governments periodically draft soldiers as the 'save our souls' managers of high profile conflicts and crises makes it more unlikely, because such drafting makes the soldiers still feel superior and in control.

Unfortunately, the Nigeria state that is supposed to mediate in this crisis is yet to evolve hegemonic order, and is very partisan in the affairs of the state. The dominant class is polarized by party affiliation, so, any faction in control of political 
power often uses it to oppress and suppress the others. In a state where this happens there will continue to be role reversal protest, and the protest will continue to generate fatal incidents

\section{Recommendations}

The scenario of soldiers-police violent clashes in Nigeria is a complex one, and one basic way out is to 'manage' the situation through specific policies and practices till generational change occurs in the military and civilian authorities. Such will take control and fade out the role reversal protest that currently hunts Nigerian soldiers and policemen. Managing the situation first means that the Nigerian society should concede certain privileges to the post military rule soldiers and allow them overcome their role reversal syndrome and get used to democratic values. This recommendation is based on some realities. First, the military is the power arm of the state. The military gives immunity to the state and state power is indeed the power of its military. Omede (2012) observes that "Before 1999, and with the exception of the period 1979-1984), the military ruled Nigeria without due regards for democratic norms and values...more often than not, one has had to wonder whether the military is above the country's constitution" (pp. 2). Even under military rule, it was observed that "The military is Babangida's constituency that he dared not offend" and that was the reason Babangida was able to last eight years as a military ruler.

Soldiers have been used to political power and privileges, and they will not easily and suddenly begin to surrender to civil authorities. It will take some time. It will have to evolve. This is why in China, for instance, "Vehicles with military plates have long been kings of the road. They are exempted from tolls and parking fees" (J.M 2013; The Economist). In the United States, with the United States Uniformed Services Privilege and Identification Card (also known as U.S. military ID, the Geneva Conventions Identification Card less commonly abbreviated USPIC), soldiers and members of the American Armed Forces are entitled to an array of privileges ranging from having access to certain restricted areas, bypassing police check stands, benefitting from certain military installations, and sometimes getting $10 \%$ off at certain stores and restaurants.

Furthermore in the United States, "Military personnel who are residents of North Carolina serving full-time active military duty outside of the state in the Armed Forces or a reserve component of the armed services, and who are home on leave for 30 days or less, do not have to purchase a license to hunt or fish" (www. /ncwildlife.org/), while, "If you are on active military duty, including New Jersey National Guard and Reserve, you are entitled to automatic extensions for your driver license, registration and inspection requirements" (www.state.nj.us/mvc/Licenses/military.htm). In India, " due to the concerted efforts of the central government and the ex- service men, the members of the armed forces 
have been given favoured treatment by a number of states in their rent control acts", and this has provided some big relief in terms payment for accommodation and the rate at which it is made. In fact, it is specifically stated in the section 45 of the law, that "the civil police cannot arrest any member of the armed forces in uniform and on duty", but can only report to the military authorities to do so (www.indianarmy.nic.in). The issue here is that if the above democratic countries that have not even witnessed military rule in their political history can concede such privileges to their soldiers, Nigeria has no reason to deny her post military rule soldiers certain privileges in order to manage them.

Apart from conceding certain privileges to soldiers as is done in other societies, Nigerian government should make concrete plans to manage the military so as to protect her nascent democracy. The assumption underlying the issue of civilian control over the military lies in the fact that if the military is not properly managed, democratically controlled and intergraded into the fabrics of the society, it can be a variety of threats to democracy" (Omede 2012:2). Nigerian society had no plans for the management of the military in her post military rule polity, and till now it appears not to have one. It is high time such plans are put in place, and they should include massive in-barracks accommodation, sporting, health and schooling facilities for soldiers and their families. This will prevent soldiers from frequent contacts with the 'bloody civilians'.

Finally, the civil society should embark on civil military relation campaign and be proactive. This will put soldiers' excesses under control till generational gap takes care of the issue. The civil society is the social umpire that uses pressure to check excesses of any segment of the society, be it soldiers, policemen, the judiciary or even the political class. Nigerian civil society organizations need to be proactive on matters of the citizens if democracy must survive.

\section{References}

Adekanye, B. (2008). Military organization in multi ethnic, segmented societies: A comparative study. Ibadan: Ababa.

Anikulapo, K. (1989). Country of Pains. Lagos: Decca Records.

Anikulapo, K. (1988). Government of Crooks. Lagos: Decca Records.

Anikulapo, K. (1989). Overtake don overtake overtake. Lagos: Decca Records.

Armed Forces Act 1993 (As Amended). Actno.105,1993 Commencement Date: 6 Jul 1994 
Danjuma, T. Y. (2000). The Nigerian army and professionalism. The Guardian, Sunday September 32000.

Diamond, L, Greene, K. \& Oyediran, O. (1997). (eds). Transition without end: Nigerian politics and civil society under Babangida. Ibadan: Vantage.

Daily Independent, January 27th 2004

Davies, James C. (1962). Toward a Theory of Revolution. American Sociological Review, 27(1): 5-19.

Dudley, B. J. (1973). Insecurity and political order. Ibadan: University of Ibadan Press.

Edmund, T. (2006).What are armed forces for? The changing nature of military roles in Europe. International Affairs, 82 (6) 1059-1075 The Royal Institute of International Affairs.

Ejogu, C. (2007). Colonial Army Recruitment Patterns and Post-Colonial Military Coups D'état in Africa: The Case of Nigeria, 1966-199. Scientia Militaria, South African Journal of Military Studies. 35(1)

Frynas, J. G. (1998). Political instability and business: Focus on Shell in Nigeria. Third World Quarterly 19, 3 457-78.

Greene, K. (1997). The remedial imperative of the Nigerian constitution, 1922 1992). In Diamond, L., Greene, K., and Oyediran, O (1997). (eds). Transition without end: Nigerian politics and civil society under Babangida. Ibadan, Vintage.

Jakobsen, T. G. (2014). The J-curve - James C. Davies' Theory of Revolutions. Popular Social Science. Fall 2012.

Momoh, A. \& Adejumobi, S. (1999). The Nigerian military and the crisis of democratic transition. Lagos: CLO

Omede, A. J. (2012).The Nigerian military: analyzing fifty years of defence and internal military and fifty years of internal military operations in Nigeria: (1960-2010). Journal of social science 33(3)293-303

www.indianarmy.nic.in

www.state.nj. 